\title{
Vertical Distribution of Euschistus heros in the Leaf Canopy of Soybean Plants
}

\author{
P. G. Silva ${ }^{1}$, M. C. S. Vieira ${ }^{1}$, E. C. S. Vieira ${ }^{1}$, I. F. Silva ${ }^{1} \&$ C. J. Ávila ${ }^{1,2}$ \\ 1 Programa de Pós-graduação em Entomologia e Conservação da Biodiversidade, Universidade Federal da \\ Grande Dourados, Dourados, MS, Brazil \\ ${ }^{2}$ Empresa Brasileira de Pesquisa Agropecuária (Embrapa Agropecuária Oeste), Dourados, MS, Brazil \\ Correspondence: P. G. Silva, Programa de Pós-graduação em Entomologia e Conservação da Biodiversidade, \\ Universidade Federal da Grande Dourados, Dourados, MS, Brazil. Tel: 55-67-99661-3394. E-mail: \\ paulagregorini@hotmail.com
}

Received: January 30, 2021

Accepted: February 28, 2021

Online Published: March 15, 2021

doi:10.5539/jas.v13n4p147

URL: https://doi.org/10.5539/jas.v13n4p147

The research is financed by $C N P q$ and EMBRAPA.

\begin{abstract}
The occurrence of phytophagous stink bugs in soybeans can result in production losses, if this pest is not properly controlled. Our objective was to study the vertical distribution (intra-plant) of nymphs and adults of Euschistus heros (Fabricius, 1798) (Hemiptera: Pentatomidae) in the leaf canopy of soybean plants, during the day. For this, fourteen soybean plants located in one meter of row were evaluated in the field, every three hours between $5 \mathrm{am}$ and $8 \mathrm{pm}$. The sampled plants were divided into three strata (upper, middle, and lower), where nymphs and adults observed were counted in each stratum and sampling period. The treatments consisted of the three strata of the soybean plants and the different sampling points performed at each time of the day represented the repetitions. An irregular distribution of E. heros nymphs and adults was observed in the three studied strata of soybean plants, during the day. At $11 \mathrm{am}$ and $2 \mathrm{pm}$, when the ambient temperature and solar radiation were highest, both the E. heros adults and the nymphs positioned preferentially on the upper stratum of the soybean plants and later migrated to the middle and lower strata when the temperature and solar radiation decreased. This information about the distribution pattern of E. heros in the soybean leaf canopy, during the day, provides knowledge for more effective monitoring and control of this pest in soybean crop.
\end{abstract}

Keywords: behavior, stink bug, Glycine max, intra-plant distribution, Pentatomidae

\section{Introduction}

Brazil is currently the second largest producer of soybean, Glycine max (L.) Merrill (Fabaceae: Phaseoleae), in the world and has achieved expanded production and productivity with each new crop. In the 2018/19 season, soybean production in the country was 115,030.1 million tons, with a cultivated area of 35,874.1 million hectares and average productivity of $3.206 \mathrm{~kg} / \mathrm{ha}(\mathrm{CONAB}, 2019)$. This expansion of soybean cultivation can increase the occurrence of phytosanitary problems, such as a higher incidence of pests, diseases, and weeds (Oliveira \& Hoffmann-Campo, 2003).

Most of the soybean phytosanitary problems are caused by insects of the Lepidoptera and Hemiptera Orders, which are normally present from the emergence of the plants to the harvest (Sosa-Gómez \& Silva, 2010). Among the hemipteran pests, the Neotropical brown stink bug Euschistus heros (Fabricius, 1798) (Hemiptera: Pentatomidae) is considered a pest of great importance, as it is the most abundant species among the main soybean pests (Smaniotto \& Panizzi, 2015) and can cause quantitative and qualitative damage to the crop, if not properly controlled (Ávila \& Grigolli, 2014; Scopel et al. 2016). According to Panizzi et al. (2012), more bioecological studies are required about $E$. heros in the soybean, once its population has increased with each crop. As the population of this pest increases, the damage caused to the soybean crop also becomes more and more significant, and in some cases, may become irreversible and cause significant loss in the production of grains or seeds (Corrêa-Ferreira \& Panizzi, 1999). 
To better understand and properly control a pest species in a given plant crop, its distribution patterns in plants must be understood (Sevacherian \& Stern, 1972). The ideal time and how to apply pesticides in a given plant crop are important information for the successful control of insect pests in crops (Sosa-Gómez \& Silva, 2010; Siqueira \& Antuniassi, 2011). Results show that the ideal time to control some pest insects in soybean crops are be the coldest times of the day, that is, at dawn and dusk. Rattes \& Jakoby (2020) reported that adult's soybean phytophagous stink bugs have a habit of moving to the upper canopy of plants in the morning while at the hottest periods of the day they move to the middle third. Zulin et al. (2018) also found that caterpillars of Chrysodeixis includens (Walker, 1858) (Lepidoptera: Noctuidae) were more exposed in the upper strata of soybean plants during the coolest times of the day, such as in the early hours of the morning and at night. Similar work was also carried out by Waite (1980) on soybean for the green stink bug, Nezara viridula (Linnaeus, 1758) (Hemiptera, Pentatomidae).

If the most suitable time for the application of the insecticide in a given crop is not determined, the control of insect pests may be compromised. When the pest is in the middle and lower part of the plants, it may be more difficult to reach the target with insecticide application; therefore, the control may be inadequate (Fernandes et al., 2006). This reinforces the importance of conducting studies on the vertical distribution of pest insects in the different crops, to determine their behavior on plants and, consequently, help ensure greater efficiency in both monitoring and management (Wilson et al., 1982).

The objective of this study was to evaluate the vertical distribution pattern (intra-plant) of the stink bug E. heros throughout the day in three different strata of soybean plants (upper, middle, and lower), to obtain information that can contribute to more efficient management of this pest in the crop.

\section{Material and Methods}

\subsection{Description of the Area}

The study was conducted in a soybean crop sown with the cultivar "Brasmax Poder" in the municipality of Itaporã, in the state of Mato Grosso do Sul, Brazil (latitude $22^{\circ} 16^{\prime} 30^{\prime \prime}$ and Longitude $54^{\circ} 49^{\prime} 0^{\prime \prime}$ ), during the 2018/2019 season. The population distribution, of nymphs and adults of the brown stink bug, was determined by sampling the upper, middle, and lower part of the soybean plants throughout the day, in the interval between 5 am and $8 \mathrm{pm}$. Thus, the evaluations were conducted at 5:00 am, 8:00 am, 11:00 am, 2:00 pm, 5:00 pm, and 8:00 $\mathrm{pm}$, on three non-consecutive days $(01 / 31 / 2019 ; 02 / 05 / 2019$, and 02/07/2019). The study started at the stage of complete filling of the grains (R6) and ended at the beginning of the physiological maturation of the soybean crop (R7).

To characterize the three strata of the soybean plants (upper, middle, and lower), a graduated ruler was used to demarcate the maximum height of the plants, this height being divided into three equivalent strata vertically, which corresponded to the upper, middle, and lower strata of the leaf canopy of soybean. At each evaluation point, a graduated ruler was placed vertically beside the plants to delimit each stratum to be sampled, in addition to a $1 \mathrm{~m}$ long ruler, horizontally arranged (Figure 1), which marked the lateral evaluation area that encompassed 14 soy plants. Based on the establishment of this sampling unit, the number of $E$. heros nymphs and adults present in the three strata of soybean plants throughout the day was evaluated. The number of insects was counted in the 14 soybean plants present in each sampling unit, considering the three strata (upper, middle, and lower) and 30 different points for each evaluation time. The upper, middle, and lower parts of the plants were considered treatments and repetitions were the different sampling points performed at each time of the day. 

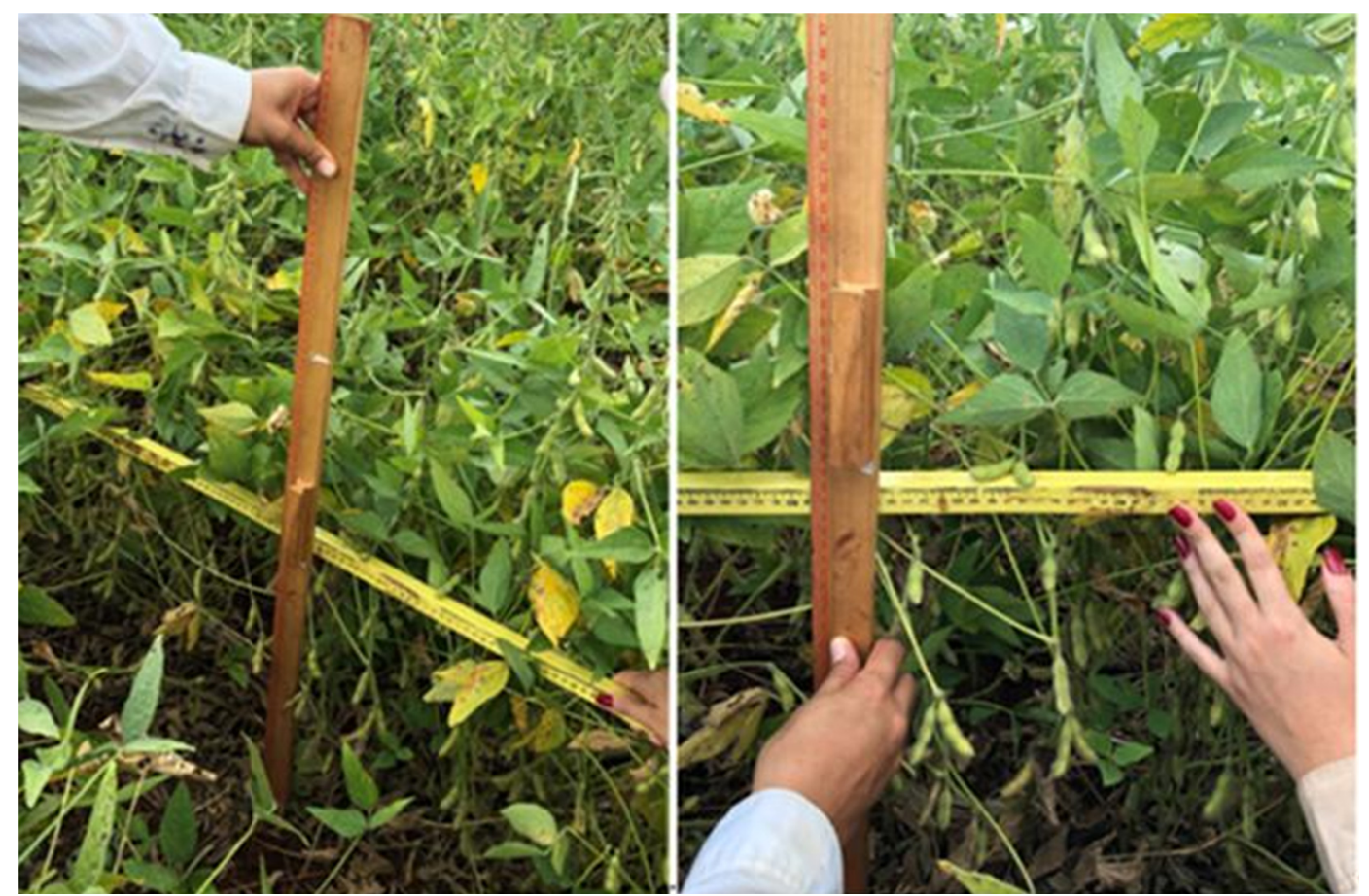

Figure 1. Detail of the sampling unit for adults and nymphs of stink bug Euschistus heros in the three strata (upper, middle, and lower) of soybean plants

\subsection{Analysis of Experimental Data}

To analyze the results, the data collected in the three days of evaluation were summed, and the average of insects observed in each stratum and sampling time was calculated. The number of $E$. heros adults and/or nymphs observed in the three strata of soybeans were subjected to analysis of variance and the treatment means compared by the Tukey test at 5\% probability. Statistical analyses were performed using the software SAS 9.3. To assist in the interpretation of the results obtained, the average data of temperature, humidity, and solar radiation on the days that the insects were evaluated in soybeans were obtained in the weather station of Embrapa Agropecuária Oeste, municipality of Dourados, in the state of Mato Grosso do Sul, Brazil $\left(22^{\circ} 16^{\prime} \mathrm{S}\right.$ and $54^{\circ} 49^{\prime} \mathrm{W}$ ).

\section{Results}

The incidence of $E$. heros nymphs was least in the lower stratum of soybean plants during the six sampling periods throughout the day (Figure 2). Likewise, the population of nymphs was less in the upper stratum of soybeans in the first two and last two evaluation times ( $5 \mathrm{am}, 8 \mathrm{am}, 5 \mathrm{pm}$, and $8 \mathrm{pm})$, being less than the density found in the middle portion of soybeans, however, without differing from that verified in the lower stratum. In these periods of greater abundance of nymphs in the middle stratum, both the average temperature and solar radiation were relatively low and the relative humidity was high (Table 1).

In the $11 \mathrm{am}$ period, the nymph population increased in the upper stratum, reaching the greatest abundance in the $2 \mathrm{pm}$ period, when more than $60 \%$ of the nymphs present in the soybean plants were found in this stratum, followed by the middle and lower strata (Figure 2). In these periods with greatest abundance of nymphs in the upper stratum, greater solar radiation in the area and less relative humidity in the environment predominated (Table 1). 


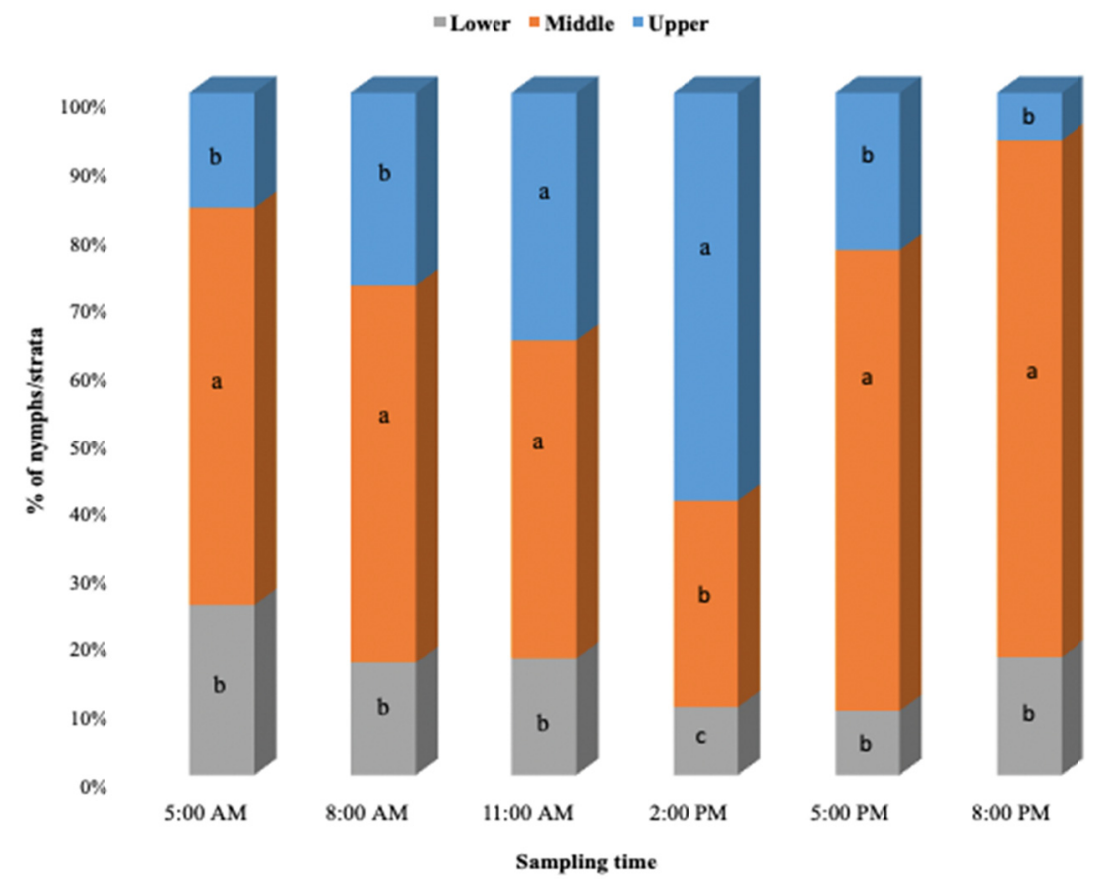

Figure 2. Percentage of nymphs of Euschistus heros in the three strata of the soybean plants (lower, middle, and upper), throughout the day, in the 2018/2019 season in Itaporã, MS, Brazil

Table 1. Average temperature $\left(\mathrm{T}^{\circ} \mathrm{C}\right)$, relative humidity $(\mathrm{RH} \%)$ and liquid radiation $\left(\mathrm{RN} \mathrm{MJ} / \mathrm{m}^{2} /\right.$ day), throughout the day, in the three days of sampling of stink bugs in soybean, in Itaporã, MS, Brazil, 2018/2019

\begin{tabular}{|c|c|c|c|}
\hline Evaluations & Temperature & Relative humidity & Net Radiation \\
\hline & ----- ${ }^{\circ} \mathrm{C}$------- & --------- \% --------- & ---- Rn MJ/m²/day ---- \\
\hline $5 \mathrm{am}$ & 22.33 & 94.33 & 0.03 \\
\hline $8 \mathrm{am}$ & 24.50 & 86.33 & 0.62 \\
\hline $11 \mathrm{am}$ & 28.53 & 68.33 & 1.57 \\
\hline $2 \mathrm{pm}$ & 29.43 & 64.67 & 1.02 \\
\hline $5 \mathrm{pm}$ & 26.63 & 69.33 & 0.65 \\
\hline $8 \mathrm{pm}$ & 25.63 & 78.67 & 0.14 \\
\hline
\end{tabular}

The E. heros adults presented a distribution pattern in the soybean leaf canopy similar to the nymphs (Figure 3). Likewise, a higher concentration of adults was observed in the upper stratum of the plants at 11 am and mainly at $2 \mathrm{pm}$, when more than $90 \%$ of adults were in this stratum at $2 \mathrm{pm}$, while in the lower stratum the adult population of the stink bug was practically non-existent in these two hotter periods (Figure 3), when the highest levels of solar radiation, temperature, and lowest values of relative humidity prevailed (Table 1). In the middle stratum of soybeans, a higher concentration of adults was observed at $5 \mathrm{am}, 5 \mathrm{pm}$, and $8 \mathrm{pm}$ hours (Figure 3), times with a predominance of lower temperatures and solar radiation and higher relative humidity (Table 1). 


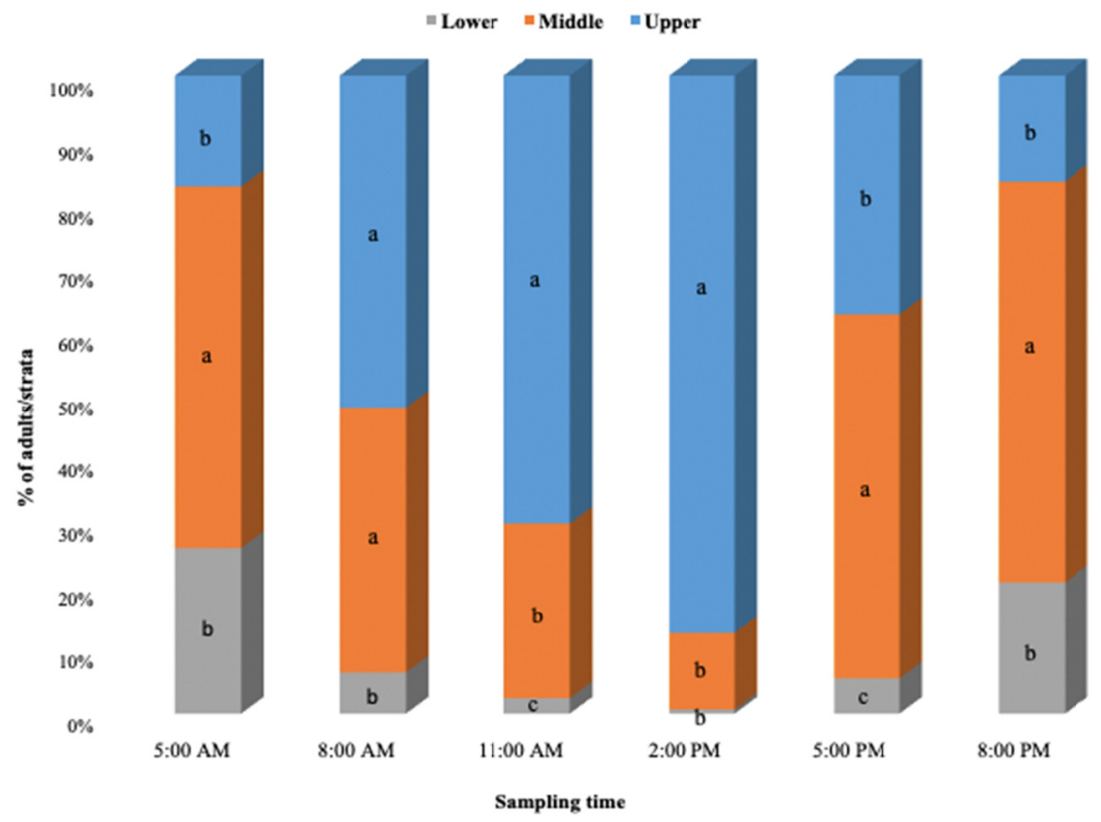

Figure 3. Percentage of Euschistus heros adults in the three strata of soybean plants (lower, middle, and upper) throughout the day in the 2018/2019 season in Itaporã, MS, Brazil

When analyzed together the distribution of nymphs + adults E. heros in the soybean leaf canopy, throughout the day, it was obvious that at 11 am and $2 \mathrm{pm}$ the insects had a higher concentration in the upper part of the soybean plants, especially compared to the occurrence in the middle and especially lower strata (Figure 4), which is similar to what was observed individually both nymphs and adults (Figures 2 and 3), when the temperature and solar radiation in the environment were high and the relative humidity of the air was low (Table 1). In the cooler times of the day, as observed at $5 \mathrm{am}, 5 \mathrm{pm}$, and $8 \mathrm{pm}$ hours, the adult + nymphs complex has preferred the middle stratum, in comparison to the upper and lower strata (Figure 4), as was also verified separately for the nymphs and adults (Figures 2 and 3).

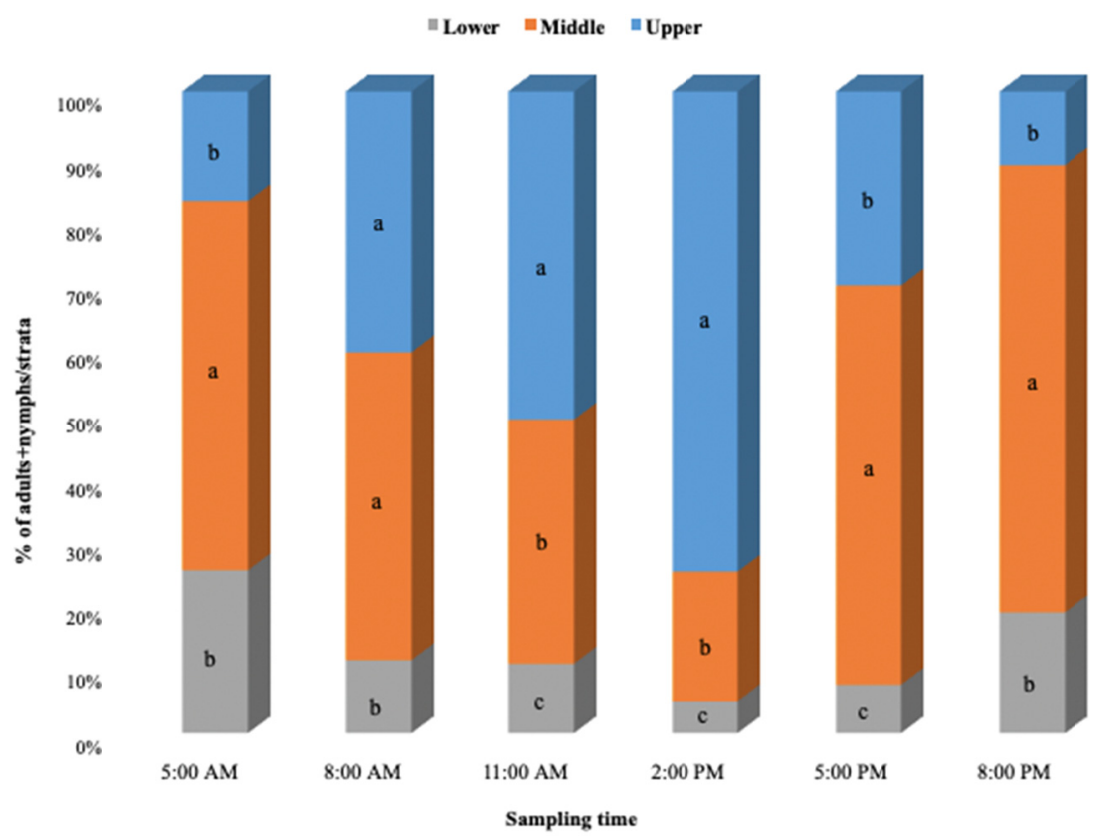

Figure 4. Total percentage of nymphs + adults of the bug Euschistus heros in the three strata of the soybean plants (lower, middle, and upper) in the 2018/2019 season in Itaporã, MS, Brazil 


\section{Discussion}

Assessing the intra-plant distribution of the E. heros in three soybean cultivars, Engel and Pasini (2019) observed that the damage caused to the pods occurs in all strata of the plants (upper, middle, and lower), although at a higher concentration in the middle and lower thirds. This information was related to the spatial variability of these bugs in soybeans, since through the damages it was possible to verify that the insects were mostly present in the middle and lower strata of the plants, which does not agree with the results for vertical distribution of this species obtained in this work, especially during the hottest times of the day, when stink bugs migrated to the top of the soy canopy.

Waite (1980) studied the behavior of nymphs and adults of $N$. viridula in soybean crop and found greater concentration in the upper part of the plants in the period from 7 to $11 \mathrm{am}$, corroborating with the results observed in this work for adults of E. heros at 11 am (Figure 3). They found that from 11 am onwards, the number of stink bugs in the upper part decreased, returning to the middle and lower strata of the plants, as was verified in this study for adults and nymphs of $E$. heros, which were concentrated in the middle region of the leaf canopy after $2 \mathrm{pm}$ (Figures 2, 3 and 4). It is believed that this behavior of migrating to the lower parts of soybeans is due to the higher temperature and insolation that occurs in the upper part of soybeans, when the insect then seeks the middle and lower part of the plants where temperatures are probably milder. Rattes and Jakoby (2020) argued that phytophagous stink bugs in soybeans, in their adult phase, have the habit of moving to the upper canopy of plants in the morning and in the hottest part of the day they move to the middle third. These reports by Rattes and Jakoby (2020) differ from those observed in this study in that the number of stink bugs in the upper part of soybeans, especially for adults, which increased between 11 am and $2 \mathrm{pm}$, when the average day temperatures were highest although they migrated for the middle part of soybeans, after these times (Figure 3 and Table 1). Zulin et al. (2018), evaluating the behavior of small and large caterpillars of $C$. includens (Walker, 1858) (Lepidoptera, Noctuidae) in the three strata of soybean plants, observed a higher concentration of caterpillars in the upper stratum of the plant under conditions of milder ambient temperatures. From $10 \mathrm{am}$, these caterpillars started to move to the middle and lower parts of the soybean plants and later they went to the top of the plants, especially around $8 \mathrm{pm}$, thus presenting an opposite result from what we observed for $E$. heros, although this was another group of soybean pests.

The fact that E. heros adults and nymphs are more exposed at the top of the soybean at times when the temperature and the insolation were highest, may be because these insects are native to the Neotropical Region (Tropical America), thus inducing them to move more intensely at these times (Panizzi \& Slansky, 1985). For nymphs, it has already been found that during the grain filling period, their visualization is difficult, since their displacement is less than that of adults, when they stay usually agglomerated in the middle part of the plants (Corrêa-Ferreira et al., 2013).

Based on the results obtained in this study, it can be inferred that chemical control of nymphs and adults of the brown stink bug should be carried out at the hottest times of the day, to increase the control efficiency of this pest, since under these conditions, insects would be more exposed to the action of chemicals applied in spraying the soybean. Nevertheless, these times, especially around $2 \mathrm{pm}$, are generally not suitable for spraying crops with chemical insecticides, because high temperature and low relative humidity prevail impairs the quality of the application of the products used to control the stink bugs. According to Weber et al. (2017), the deposition of chemicals in the middle and lower strata of the leaf canopy of plants is lower compared to deposition in the upper stratum. Most of the product applied in spraying, whether in high or low volume, is retained in the upper layer, with approximately ten times more coverage in the upper layer than in the lower layer (Boschini et al. 2008; Barbosa et al., 2009). This information reinforces the feasibility of controlling the stink bugs when they are concentrated in the upper part of the soybean plants, between $11 \mathrm{am}$ and $2 \mathrm{pm}$, as long as there is have adequate temperature and relative humidity conditions for spraying. Dutra et al. (2012) found that the caterpillars of Spodoptera frugiperda (J.E. Smith, 1797) (Lepidoptera: Noctuidae), in general have a greater preference for the upper part of cotton plants, during the entire period of their development, a behavior that provides better control of this pest, when insecticide applications are carried out in the crop.

At times of the day when the ambient temperature and solar radiation are higher and the relative humidity of the air is lower, both adults and E. heros nymphs prefer to position themselves in the upper layer of soybean plants, moving to the middle and lower strata as the temperature and solar radiation decrease and the relative humidity increases. 


\section{Acknowledgements}

The authors are very grateful for the support of the Embrapa Agropecuária Oeste, the Conselho Nacional de Desenvolvimento Científico e Tecnológico (CNPq), the Coordenação de Aperfeiçoamento de Pessoal de Nível Superior (Capes) and the Universidade Federal da Grande Dourados (UFGD).

\section{References}

Ávila, C. J., \& Grigolli, J. F. J. (2014). Pragas de soja e seu controle. Tecnologia e Produção: Soja 2013/2014. Embrapa Agropecuária Oeste.

Barbosa, R. N., Griffin, J. L., \& Hollier, C. A. (2009). Technical Note: Effect of spray rate and method of application in spray deposition. Applied Engineering in Agriculture, 25(2), 181-184. https://doi.org/ $10.13031 / 2013.26327$

Boschini, L., Contiero, R. L., Macedo Júnior, E. K., \& Guimarães, V. F. (2008). Avaliação da deposição da calda de pulverização em função da vazão e do tipo de bico hidráulico na cultura da soja. Acta Scientiarum. Agronomy, 30(2), 171-175. https://doi.org/10.4025/actasciagron.v30i2.1789

CONAB (Companhia Nacional de Abastecimento). (2019). Acompanhamento da safra brasileira de grãos 2018/19-Décimo segundo levantamento. Retrieved September 11, 2019, from http://www.conab.gov.br

Corrêa-Ferreira, B. S., \& Panizzi, A. R. (1999). Percevejos da soja e seu manejo (pp. 81-84). Londrina: Embrapa Soja.

Corrêa-Ferreira, B. S., Castro, L. C., Roggia, S., Cesconetto, N. L., Costa, J. M., \& Oliveira, M. C. N. (2013). MIP-Soja: Resultados de uma tecnologia eficiente e sustentável no manejo de percevejos no atual sistema produtivo da soja. Londrina: Embrapa Soja.

Dutra, C. C., Fernandes, M. G., Fernandes, W. D., \& Busoli, A. C. (2012). Distribuição vertical de Spodoptera frugiperda (J.E. Smith) (Lepidoptera: Noctuidae) em plantas de algodão (Gossypium hirsutum L.). Agrarian, 5(15), 7-13.

Engel, E., \& Pasini, M. P. B. (2019). Distribuição intraplanta. Cultivar Grandes Culturas, 240, 22-25.

Fernandes, M. G., Silva, A. M., Degrande, P. E., \& Cubas, A. C. (2006). Distribuição vertical de lagartas de Alabama argillacea (Hubner) (Lepidoptera: Noctuidae) em plantas de algodão. Manejo Integrado de Plagas y Agroecología, 78(1), 28-35.

Oliveira, L. J., \& Hoffmann-Campo, C. B. (2003). Alternativas para manejo de corós e do tamanduá da soja. In B. S. Corrêa-Ferreira (Ed.), Soja orgânica: Alternativas para o manejo dos insetos-pragas (pp. 33-54). Londrina: Embrapa Soja.

Panizzi, A. R., \& Slansky Jr., F. (1985). Review of phytophagous pentatomids (Hemiptera: Pentatomidae) associated with soybean in the Americas. Florida Entomologist, 68(1), 184-214. https://doi.org/10.2307/ 3494344

Panizzi, A. R., Bueno, A. de F., \& Silva, F. A. C. (2012). Insetos que atacam vagens e grãos. In C. B. Hoffmann-Campo, B. S. Corrêa-Ferreira, \& F. Moscardi (Eds.), Soja: Manejo integrado de insetos e outros artrópodes-praga (pp. 335-420). Brasília: Embrapa.

Rattes, J. F., \& Jakoby, G. L. (2020). Monitoramento de percevejos. Cultivar Grandes Culturas, 248, 12-17.

Scopel, W., Salvadori, J. R., Panizzi, A. R., \& Pereira, P. R. V. S. (2016). Danos de Euschistus heros (F.) (Hemiptera: Pentatomidae) em soja infestada no estádio de grão cheio. Revista Agropecuária Catarinense, 29(3), 81-84.

Sevacherian, V., \& Ster, V. M. (1972). Spatial distribution patterns of lygus bugs in California cotton fields. Environmental Entomology, 1(6), 695-704. https://doi.org/10.1093/ee/1.6.695

Siqueira, J. L., \& Antuniassi, U. R. (2011). Inspeção periódica de pulverizadores nas principais regiões de produção de soja no Brasil. Energia da Agricultura, 26(4), 92-100. https://doi.org/10.17224/EnergAgric. 2011v26n4p92-100

Smaniotto, L. F., \& Panizzi, A. R. (2015). Interactions of selected species of stink bugs (Hemiptera: Heteroptera: Pentatomidae) from leguminous crops with plants in the Neotropics. Florida Entomologist, 98(1), 7-17. https://doi.org/10.1653/024.098.0103 
Sosa-Gómez, D. R., \& Silva, J. J. (2010). Neotropical brown stink bug (Euschistus heros) resistance to methamidophos in Paraná, Brazil. Pesquisa Agropecuária Brasileira, 45(7), 767-769. https://doi.org/ 10.1590/S0100-204X2010000700019

Waite, G. K. (1980). The basking behavior of Nezara viridula (L.) (Pentatomidae: Hemiptera) on soybeans and its implication in control. Australian Journal of Entomology, 19(2), 157-159. https://doi.org/10.1111/ j.1440-6055.1980.tb00978.x

Weber, N. C., Santos, E. M. dos, Russini, A., \& Silva, F. F. da. (2017). Deposição de calda ao longo do dossel na cultura da soja utilizando pulverizador equipado com controlador de fluxo. Revista Engenharia na Agricultura, 25, 459-468. https://doi.org/10.13083/reveng.v25i5.843

Wilson, L. T., Gutierrez, A. P., \& Hogg, D. B. (1982). Within-plant distribution of cabbage looper, Trichoplusia $n i$ (Hubner) on cotton: development of a sampling plan for eggs. Entomological Society of America, 11(1), 251-254. https://doi.org/10.1093/ee/11.1.251

Zulin, D., Ávila, C. J., \& Schlick-Souza, E. C. (2018). Population Fluctuation and Vertical Distribution of the Soybean Looper (Chrysodeixis includens) in Soybean Culture. American Journal of Plant Sciences, 9(7), 1544-1556. https://doi.org/10.4236/ajps.2018.97113

\section{Copyrights}

Copyright for this article is retained by the author(s), with first publication rights granted to the journal.

This is an open-access article distributed under the terms and conditions of the Creative Commons Attribution license (http://creativecommons.org/licenses/by/4.0/). 